\title{
Bees and pollination in our changing environment
}

\author{
SWT Batra \\ Bee Research Laboratory, Bldg 476, USDA, ARS, Beltsville, MD 20705, USA
}

(Received 12 December 1994; accepted 9 July 1995)

\begin{abstract}
Summary - This is a review of the early literature demonstrating the adequacy of pollination by local bee populations before intensive and extensive agricultural practices. Although not always the best pollinators, honey bees were used in crops when populations of other bees crashed. Publications on managing and conserving pollen bees are included because interest in sustainable agriculture and biodiversity of bees and host plants is increasing.
\end{abstract}

Apoidea / pollination / sustainable agriculture / management

\section{INTRODUCTION}

Due to their fuzzy bodies and frequent, consistent flower-visiting habits, bees (Apoidea) are usually the most effective pollinators of the numerous crops and wild plants that are not wind-pollinated. The study of this important subject is difficult, due to the complex interactions between the bees, their hosts, and various environmental and economic conditions; also, existing knowledge is widely dispersed in the biological and other literature (for example, Clements and Long, 1923; Grant, 1949; Schmid, 1975). This review of interesting and still timely publications was compiled because many of the early reports are not accessible by computerized literature search, and others are in journals not searched by pollination biolo- gists. Thus, there have been many oversights and omissions. In spite of many published reports to the contrary, most people continue to simplistically credit the common honey bee (Apis mellifera $\mathrm{L}$ ) with nearly all of the insect pollination in nature (for example, Barclay and Moffett, 1984) and agricultural crops (Anonymous, 1973; Cheung, 1973; McGregor, 1976; Levin, 1983; Robinson et al, 1989; references in Southwick and Southwick, 1992).

At issue is the logical valuation of publicly shared assets (bees), most species and populations belonging to nobody, yet benefiting all of us through pollination (in economics, a condition referred to as an 'externality'). Honey bees and certain stingless honey bees were brought into domestication or management long ago, but for the 
purpose of their honey and wax production rather than for any superior pollinating abilities. Pollination of crops was not a consideration at that time. Because they were owned by beekeepers and thus already had value in the economic system (in economic terms, were 'internalized') and could be managed, honey bees began to be used as pollinators when populations of other bees (= pollen bees) and crop yields declined, due to new adverse agronomic and environmental impacts. The challenge of bee and pollination economics even launched J K Galbraith's distinguished career in economics (Voorhies et al, 1933). The honey bee is a good general pollinator, but not for all crops, under all conditions, just as the prolific freshwater carp is a good fish, but others may be more suited to different environments such as the sea, tastier, or less bony. The pollination need is similar to that in fisheries and aquaculture, where, as 'free' wild fish populations decline, fish prices rise, and ever more species are brought into domestication (aquaculture). Since the Roman empire, the common carp has been the world's major cultured food fish, but due to recently reduced populations of wild fish there are now many more (in the Washington DC area, farm-raised fish now predominate in shops).

The rational assessment and valuation of things that have been historically considered 'free', such as clean air, adequate water, fish, and pollinators, has become a major concern in ecology, as scarcities of such things increase (Meyer and Turner, 1992; Vitousek, 1994). It seems to be human nature to unwittingly use up or destroy our resources, unless they can be specifically identified as worth saving, for economic reasons, or as ultimately beneficial to human life. Economic rationales such as, "what is it good for?" may be disguised as environmental, religious and aesthetic values in many cultures.

Thus, it is time to protect our native beneficial Apoidea through habitat conserva- tion and sustainable agriculture, and to augment them with selected, managed pollinators that are best adapted to most efficiently pollinate the flowers of our crops.

\section{DELAYED RECOGNITION}

The bias in favor of maladapted but manageable honey bees is clearly illustrated by alfalfa (lucerne) pollination. Henslow (1867) first reported the tripping mechanism of the flower, and he noted that honey bees took only nectar, without tripping (pollinating). This was confirmed repeatedly (Müller, 1873; Brand and Westgate, 1909; Westgate, 1911; Piper et al, 1914; Hadfield and Calder, 1936; Tysdal, 1940; Knowles, 1943; Linsley, 1946; Akerberg and Lesins, 1949; Stephen, 1955; Semmens et al, 1993; many more recent authors). Other species of bees (especially Megachile) tripped the flowers and were soon found by astute observers to be efficient pollinators (Brand and Westgate, 1909; Piper et al, 1914; Archer, 1917; Sladen, 1918; Helmbold, 1929; Hadfield and Calder, 1936; Salt, 1940; Tysdal, 1940; Knowles, 1943; Stapel, 1943; Linsley, 1946; Akerberg and Lesins, 1949). Recommendations for conservation of habitats where bees could nest (Vansell, 1951; Franklin, 1952; Stephen, 1955), and the rearing or management of selected bee species (Knowles, 1943; Peck and Bolton, 1946; Bohart, 1972) began to be made as populations of native bees crashed, due to the new use of insecticides and the continuing destruction of habitat. In 1943, a Canadian grower, WD Clarke, first raised Megachile for alfalfa pollination (Peck and Bolton, 1946). Nevertheless, because honey bees were manageable and could distribute pollen from heat-stressed, open flowers, they still were promoted by scientists and others for alfalfa pollination everywhere (Akerberg and Lesins, 1949; Vansell, 1951; Franklin, 1952; Anon, 1973; Levin, 1983; Olmstead and 
Wooten, 1987; Robinson et al, 1989). Recently, economic data confirming the superiority of managed Megachile rotundata F and Nomia melanderi Ckll were published (Olmstead and Wooten, 1987; Peterson et al, 1992; Wichelns et al, 1992).

A similar situation exists in apples and related orchard crops. Before the introduction of insecticides, early observers reported adequate pollination by native bees alone, and most of them recommended the conservation of uncultivated lands in or near orchards to provide habitat for their nesting (Sax, 1922; Hutson, 1926; Wilson, 1926, 1933; Atwood, 1933; Voorhies et al, 1933; Brittain and Newton, 1934; Howlett, 1934; Musychenko, 1937; Orsono-Mesa, 1947). Musychenko (1937) first recommended the management of pollen bees to augment their populations, and a Japanese apple grower, E Matsuyama, seems to have been the first to do so, using Osmia cornifrons (Rad) in the 1930s (Maeta and Kitamura, 1981). At present, this superior bee is managed to pollinate a third of Japan's apples (Sekita and Yamada, 1993) and its use has spread to other countries (Parker et al, 1987). Although polylectic honey bees are used in orchards, they obtain little nectar, and, having a long flight range, they tend to stray, to forage elsewhere (Voorhies et al, 1933; Cheung, 1973). Growers thus pay for hive rentals that may benefit their neighbors or even undesirable weeds (Voorhies et al, 1933; Loring, 1981; Goltz, 1987; MacFawn, 1993). Because most managed pollen bees are gentle, easy to keep, prefer the crop host, have short flight ranges, stay in the orchard, work rapidly, and collect and distribute pollen efficiently, interest in keeping them is increasing. O lignaria propinqua $\mathrm{Cr}, \mathrm{O}$ cornuta (Latr), and other Osmia spp are now being managed (Parker et al, 1987; Torchio, 1990, 1991; Bosch, 1994; Bosch and Blas, 1994; Marquez et al, 1994).

Blueberries and cranberries (Vaccinium spp) are other crops that are better polli- nated by pollen bees than honey bees, as discovered by Shaw et al (1939), and repeatedly confirmed (Wood, 1961, 1979; Boulanger et al, 1967; Bigras-Huot and Jobin, 1972; Kevan et al, 1983; Parker et al, 1987; Harder and Thomson, 1989). The management of several new pollinators is recently developing (Parker et al, 1987; Batra, 1994; Stubbs et al, 1994). New techniques for mass rearing bumble bees (Ptacek, 1985; Röseler, 1985; van Heemert et al, 1990; Vogel and Westerkamp, 1991) permit their field use in blueberries and cranberries, and their widespread use in glasshouses on other crops, such as the hothouse tomato. For best yields, these crops require buzz-pollination, which honey bees have long been known to be unable to perform (Fink, 1896; Herbst, 1918; Orsono-Mesa, 1947; Rick, 1950). Unfortunately, the findings of these authors were ignored for decades, and instead of efforts to manage the best pollinators, honey bees were used.

Different pollinators have different pollinating abilities, which vary with the bee species (its size, hairiness, quickness, fidelity, longevity, learning ability, flight range, cold tolerance, season, flower handling ability, etc). The appropriate match between each bee species and its host is critical, because a poorly adapted pollinator may even function as a parasite by removing nectar and pollen, without achieving pollination. Some early reports were relatively neglected (Allard, 1911; Green, 1955; Fronk and Slater, 1956; Medler, 1956; ), but as knowledge of ecosystem dynamics and change increased, more attention was paid to this subject, especially the relationships between native bees, honey bees and plants (Primack and Silander Jr, 1975; Schemske and Horvitz, 1984; Herrera, 1987, 1989; Harder and Thomson, 1989; Thomson and Thomson, 1989, 1992; Young and Stanton, 1990; Westerkamp, 1991a,b; Willmer, 1991; Wilson and Thomson, 1991; Chagnon et al, 
1993; Kunin, 1993; Cresswell, 1994; Marquez et al, 1994a,b).

\section{THE CONSĘRVATION OF NATIVE BEES}

Because unmanaged native bees are so important as pollinators of crops and wild plants, and interest in maintaining biodiversity is growing (Prescott-Allen and PrescottAllen, 1986; Parker et al, 1987; Torchio, 1991), general awareness of the diversity of bee species and public knowledge of their value to ecosystems is increasing (Morse, 1960; Malyshev, 1963; Michener, 1979; Schreck and Schedl, 1979; Westrich, 1983b, 1990; MacKenzie and Winston, 1984; ScottDupree and Winston, 1987; Zöckler, 1988; Banaszak, 1989a; O'Toole, 1993; Adams and Senft, 1994). The impacts of various human activities on populations of bees and on their habitats have been studied, especially in Europe, where long and detailed records have been kept (Westrich, 1990). Impacts in Europe include forestry, cultivation patterns, pollution, drainage, irrigation, construction, parks as refuges, urbanization, herbicides and insecticides, road traffic, weed invasions, and host plant destruction (Emeis, 1964; Pawlikowski, 1967; Benedek, 1970, 1972; Haeseler, 1972, 1978, 1982; Peters, 1972; Jacob-Remacle, 1976, 1984, 1992; Williams, 1982, 1986, 1989; Banaszak, 1983, 1985, 1987, 1989b; Prescott-Allen, 1986; Banaszak and Manole, 1987; Kosior, 1987; Tanacs, 1987; Archer, 1989; Kratochwil and Klatt, 1989; Pawlikowski, 1989a, b; Torres et al, 1989; Fussell and Corbet, 1991; Schwenninger, 1992; Westrich, 1983a; Osborne et al, 1991; Vogel and Westerkamp, 1991; Lagerlöf et al, 1992; Donath, 1994).

Recent studies have documented similar impacts and population changes in Japan (Munakata, 1984) and in North and Central America (Plowright et al, 1978; Miliczky and Osgood, 1979; Wood, 1979; Ginevan et al,
1980; Johansen et al, 1983; Hansen and Osgood, 1984; Thomson et al, 1985; Kevan et al, 1990b; Vinson and Frankie, 1990; Johansen and Mayer, 1990; Kevan et al 1990a).

\section{EXOTIC POLLINATORS}

The accidental or deliberate importation of pollinators into new geographic regions has lately become a concern to some environmentalists. The widespread European honey bee and bumble bees imported into some regions (Dunning, 1886) may be displacing native bees or other pollinators of the native flora, or they may provide unsatisfactory pollination of these plants (Pyke and Balzer, 1983; Vogel and Westerkamp, 1991; Westerkamp, 1991; Wilson and Thomson, 1991; Thomson and Thomson, 1992; Kato, 1993; Paton, 1993). Bombus terrestris $L$ is now widely distributed for pollination of crops and is another potential competitor (Donovan, 1990; Semmens et al, 1993; Kato, 1993). Although several species of solitary bees have been distributed to new regions for pollinating crops, they are less likely to displace native bees than is the ubiquitous European honey bee, due to their greater host-specificity, climatic limitations, shorter foraging ranges, specific conditions for nesting, and brief adult life (Donovan, 1990).

The principles that apply to the importation and establishment of exotic pollinators resemble those of classical biological control (Batra, 1982), in which beneficial organisms are sought near the center of origin of the problem-causing organism in a similar climate, observed and tested for lack of harm to other beneficial or rare organisms, imported into quarantine where their parasites can be eliminated, tested with hosts again, in confinement and then released for a specific purpose into their new environments. Considerable effort has gone into identifying the most efficient pollinators of 
several Eurasian crops that may be worthy of importation into North America, South America, Australia and New Zealand where native pollinators are not well adapted to pollinate these crops (reviewed in Parker et al, 1987). Conversely, American pollinators of sunflowers, cotton, passion fruit, squashes and gourds, avocado, tomato, chili, blueberries and cranberries have been studied in areas where these crops are believed to have originated, the goal being to introduce their pollinating bees into areas where the crops are now grown without their most efficient pollinators (Parker et al, 1987).

Large human populations can currently only be maintained by agriculture, which must alter native environments. Humans, like all organisms, may be expected to increase in population (absent natural enemies), until all available resources are fully exploited, either directly (as in agriculture), or indirectly, for example, when biota and other natural resources have been assessed and then reserved for possible future value (in economic terms, internalized). The impact of humans is large, complex, and irreversible (Vitousek, 1994). One way to provide for more habitat in which to conserve native bees and other biodiversity, as well as nonrenewable resources, would be to improve the yields on existing crop lands. This can be accomplished, in part, by introducing the most efficient pollinators for these crops.

Résumé - Les abeilles et la pollinisation dans un environnement changeant. Les recherches antérieures ont montré que, avant le développement de l'agriculture intensive, des monocultures et l'utilisation des pesticides, la pollinisation des fleurs par les populations d'abeilles indigènes (Apoïdés) était satisfaisante. Quand ces populations d'abeilles ont décliné, des abeilles moins efficaces (principalement l'abeille domestique Apis mellifera) ont été utilisées pour la pollinisation parce qu'elles étaient déjà utilisées pour la production de miel et de cire. Il y a des dizaines d'années des chercheurs ont identifié les insectes pollinisateurs les mieux adaptés et décrit leurs habitats et leurs modes d'élevage. La prise de conscience actuelle de la destruction de leurs habitats, le besoin de biodiversité parmi les pollinisateurs, une plus grande connaissance de la spécificité insecteplante, la valeur économique des pollinisateurs choisis, et les menaces pesant actuellement sur les populations d'abeilles domestiques ont fait de la pollinisation par les apoïdés en général un sujet d'actualité.

Cette publication présente une revue des références les plus intéressantes en incluant les recherches antérieures qui sont rarement citées mais cependant encore très actuelles. Elle décrit également les conditions historiques qui ont favorisé l'utilisation de l'abeille domestique, les implications économiques de la pollinisation, les changements dans l'environnement et dans les populations d'apoïdés, l'impact des abeilles domestiques étrangères et l'importance qu'il y a à comprendre le comportement des insectes pollinisateurs sur les fleurs.

\section{apoïdés / pollinisation / gestion des pol- linisateurs / agriculture}

\section{Zusammenfassung - Bienen und Bestäubung in unserer sich wandelnden Umwelt: ein kurzer Überblick über alte und neue Literatur. Frühere Untersu- chungen vor Entwicklung der intensiven Landwirtschaft mit Monokulturen und Pesti- ziden haben ergeben, daß die heimische Bienenpopulation eine adäquate Bestäu- bung geleistet hat. Nachdem die Wildbie- nenpopulation zurückging, wurden die Honigbienen vermehrt für die Bestäubung eingesetzt, obwohl sie weniger leisteten. Ein Hauptgrund war wohl, daß zu diesem Zeitpunkt bereits eine Technik der Bienen-}


haltung zur Erzeugung von Wachs und Honig vorhanden war. Alternative Bestäuber wurden bereits vor Jahrzehnten von problembewußten Wissenschaftlern bestimmt und Empfehlungen für ihre Haltung und den Schutz ihres Lebensraums gegeben. Zur Zeit rückt die Zerstörung der Umwelt immer deutlicher in unser Bewußtsein. Außerdem erkennen wir, daß die Biodiversität der Bestäuber notwendig ist und daß eine genaue Kenntnis über die Pflanze-Bestäuber-Spezifität gebraucht wird. Der ökonomische Wert von selektierten Bestäubern und die Bedrohung der Honigbienenpopulation hat neuerdings die Bestäubung durch Apoidea zu einem wichtigen Diskussionsthema gemacht. Es werden einige interessante Literaturzitate aufgelistet, in denen auch selten zitierte, aber immer noch gültige ältere Forschungen über Bestäubung enthalten sind. Weiter läßt sich die historische Entwicklung der Ausrichtung der Bestäubungspraxis vorwiegend auf Honigbienen verfolgen. Auch die Ökonomie der Bestäubung, die Veränderungen in der Umwelt und in der Population der Apoidea, die Wirkung der in vielen Erdteilen ursprünglich nicht heimischen Apis mellifera und die Wichtigkeit unseres Verständnisses für das Verhalten auf den Blüten wird durch die Literaturzitate deutlich.

\section{Apoidea / Bestäubung / nachhaltige Landwirtschaft / Bewirtschaftung}

\section{REFERENCES}

Adams S, Senft D (1994) The busiest of bees. Agric Res 42, 8-12

Akerberg E, Lesins K (1949) Insects pollinating alfalfa in central Sweden. Ann R Agric Coll Sweden 16, 630643

Allard HA (1911) Some experimental observations concerning the behavior of various bees in their visits to cotton blossoms. Am Nat 45, 607-685

Anonymous (1973) Winged nations. Agric Res 21, 2

Archer LC (1917) The production of alfalfa seed in southern Idaho. Univ Idaho Agric Exp Sta Bull 101, 1
Archer ME (1989) The wasps and bees (Hymenoptera: Aculeata) of Allerthorpe Common before and after coniferization. Naturalist (Leeds) 114, 129-136

Atwood CE (1933) Studies on the Apoidea of western Nova Scotia with special reference to visitors to apple bloom. Can J Res 9, 443-457

Banaszak J (1983) Ecology of bees (Apoidea) of agricultural landscape. Polish Ecol Stud 9, 421-505

Banaszak J (1985) Rural parks as refuges of the fauna of insects which pollinate plants. Chronmy Przyr Ojcz 41, 5-9

Banaszak J (1987) Fauna of wild bees of Wielkopolskokujawska lowland during the last 50 years. Badania Fizjogr Polska Zachodnia Ser C Zool 67-77

Banaszak J (1989a) Investigations on natural resources of pollinators. In: Unconventional Methods in Lucerne Breeding Proc, Medicogo sativa Working Group Meeting, Radzikow, Poland

Banaszak J (1989b) Protection of pollinating insects in Poland. Kosmos 38, 363-374

Banaszak J, Manole T (1987) Diversity and density of pollinating insects (Apoidea) in the agricultural landscape of Rumania. Polskie Pismo Entomol 57, 747766

Barclay JS, Moffett JO (1984) The pollination value of honey bees to wildlife. Am Bee J 124, 497-498, 551

Batra SWT (1982) Biological control in agroecosystems. Science 25, 134-139

Batra SWT (1994) Anthophora pilipes villosula Sm (Hymenoptera: Anthophoridae), a manageable Japanese bee that visits blueberries and apples during cool, rainy, spring weather. Proc Entomol Soc Wash 96, 98-119

Benedek P (1970) Effects of plot size, stand density and state of flowering on wild bees pollinating lucerne. Acta Agron Acad Sci Hungaricae 19, 283-292

Benedek P (1972) Possible indirect effect of weed control on population changes of wild bees pollinating lucerne. Acta Phytopathol Acad Sci Hungaricae 7, 267-278

Bigras-Huot F, Jobin LJ (1972) La pollinisation du bleuet au Lac-St-Jean. I. Role de l'abeille domestique Apis mellifera L. Ann Soc Entomol Quebec 16, 138-169

Bohart GE (1972) Management of wild bees for the pollination of crops. Annu Rev Entomol 17, 287-312

Bosch J (1994) Improvement of field management of Osmia cornuta (Latreille) (Hymenoptera, Megachilidae) to pollinate almond. Apidologie 25, 71-83

Bosch J, Blas M (1994) Foraging behaviour and pollinating efficiency of Osmia cornuta (Latr) and Apis mellifera $\mathrm{L}$ on almond (Hymenoptera, Megachilidae and Apidae). Appl Entomol Zoo 28-29, 1-9

Boulanger LW, Wood GW, Osgood EA, Dirks CO (1967) Native bees associated with the lowbush blueberry in Maine and eastern Canada. Maine Agric Exp Sta Canada Agric Res Sta Tech Bull 26 
Brand CJ, Westgate JM (1909) Alfalfa in cultivated rows for seed production in semiarid regions. US Dept Agric Bur Industry Circular No 24, 1-23

Brittain WH, Newton DE (1934) Further observations on the pollen constancy of bees. Can J Res 10, 255263

Chagnon M, Gingras J, de Oliveira D (1993) Complementary aspects of strawberry pollination by honey and indigenous bees (Hymenoptera). J Econ Ento$m o / 86,416-420$

Cheung SNS (1973) The fable of the bees: an economic investigation. J Law Econ 16, 11-33

Clements FE, Long FL (1923) Experimental pollination, an outline of the ecology of flowers and insects, Carnegie Inst, Washington, DC, USA

Cresswell JE (1994) A method for quantifying the gene flow that results from a single bumblebee visit using trangenic oilseed rape, Brassica napus L cv Westar. Transgenic Res 3, 1343-1377

Donath H (1994) Gefährdung und Schutz unserer Hummeln. Naturschutz-Arbeit Berlin Brandenburg 21, 1-5

Donovan BJ (1990) Selection and importation of new pollinators to New Zealand. NZ Entomol 13, 26-32

Dunning JW (1886) The importation of humble bees into New Zealand. Trans A Entomol Soc London 6, 32-34

Emeis W (1964) Beobachtungen über den Rückgang häufiger Bienenarten in Schleswig-Holstein. Faunist Mitt Norddeutschland 2, 152-154

Fink B (1896) Pollination and reproduction of Lycopersicon esculentum. Minn Bot Stud Bull 9, 636-643

Franklin WW (1952) Wild bees as supplementary pollinators. Am Bee J 92, 290-291

Fronk WD, Slater JA (1956) Insect fauna of cucurbit flowers. JKans Entomol Soc 29, 141-146

Fussell M, Corbet SA (1991) Bumblebee habitat requirements: a public survey. Acta Hortic 288, 159-163

Ginevan ME, Lane DD, Greenberg L (1980) Ambient air concentration of sulfur dioxide affects flight activity in bees. Proc Natl Acad Sci USA 77, 5631-5633

Goltz L (1987) Migratory beekeeping. Am Bee J 127 , $29-46$

Grant V (1949) Arthur Dobbs (1750) and the discovery of the pollination of flowers by insects. Torreya 76 , 217-219

Green JM (1955) Bumblebees breed cotton too! What's New in Crops and Soils 7, 1-2

Hadfield JW, Calder RA (1936) Lucerne (Medicago sativa). Investigations relative to pollination and seed production in New Zealand. NZJ Sci Tech 17, 577594

Haeseler V (1978) Zum Auftreten aculeater Hymenopteren in gestörten Hochmoorresten des Fintlandsmoores. Drosera 78, 57-76

Haeseler V (1982) Ameisen, Wespen und Bienen als Bewohner gepflasterter Bürgersteige, Parkplätze und Strassen (Hymenoptera: Aculeata). Drosera 82 17-32

Haeseler V (1972) Man-made habitats (deforested area, gravel pit, city gardens and parks) as refuges for insects, exemplified by the Hym Aculeata. Zool $\mathrm{Jb}$ Syst 99, 133-212 (in German)

Hansen RW, Osgood EA (1984) Effects of a split application of Sevin-4-oil on pollinators and fruit set in a spruce-fir forest. Can Entomol 116, 457-464

Harder LD, Thomson JD (1989) Evolutionary options for maximizing pollen dispersal of animal-pollinated plants. Am Nat 133, 323-344

Helmbold $F$ (1929) Untersuchungen über die Befruchtungsverhältnisse, über die Bedingungen und über die Vererbung der Samenerzeugung bei Luzerne (Medicago sativa und Bastardluzerne). Z Pflanzenzuchtung 14, 113-173

Hensiow G (1867) Note on the structure of Medicago sativa as apparently affording facilities for the intercrossing of distinct flowers. J Linn Soc Bot $9,327-329$

Herbst $P$ (1918) Über Lautäußserungen einiger chilenischer Blumenwespen (Apidae). Dsch Entomol Z 93-96

Herrera CM (1987) Components of pollinator 'quality': comparative analysis of a diverse insect assemblage. Oikos 50, 79-90

Herrera CM (1989) Pollinator abundance, morphology, and flower visitation rate: analysis of the 'quality' component in a plant-pollinator system. Oecologia $80,241-248$

Howlett FS (1934) Pollination of the apple in Ohio. Bull Ohio Agric Exp Sta 167, 65-70

Hutson R (1926) Relation of the honeybee to fruit pollination in New Jersey. NJ Agr Exp Sta Bull 434, 2-32

Jacob-Remacle $A$ (1976) Une opération nichoirs artificiels pour hyménoptères dans 3 jardins de Liège. Bull Ann Soc $R$ Belge Entomol 112, 219-242

Jacob-Remacle A (1984) Étude écologique du peuplement d'hyménoptères aculéates survivant dans la zone la plus urbanisée de la ville de Liège. Bull Ann Soc R Belge Entomol 120, 241-262

Jacob-Remacle A (1992) Les abeilles solitaires: des insectes pollinisateurs peu connus. Insectes 84,20 22

Johansen CA, Mayer DF, Eves JD, Kious CW (1983) Pesticides and bees. Environ Entomol 12, 1513-1518

Johansen CA, Mayer DF (1990) Pollinator Protection: A Bee and Pesticide Handbook, Wicwas Press, Cheshire, CT, USA

Kato M (1993) Impacts of the introduction of Bombus terrestris colonies upon pollination mutualism in Japan. Honeybee Sci 14, 110-114 (in Japanese)

Kevan PG, Gadawski RM, Kevan SD, Gadawski SE (1983) Pollination of cranberries, Vaccinium macrocarpon, on cultivated marshes in Ontario. Proc Entomol Soc Ontario 114, 45-53 
Kevan PG, Clark EA, Thomas VG (1990a) Pollination: a crucial ecological and mutualistic link in agrotorestry and sustainable agriculture. Proc Entomol Soc Ontario 121, 43-48

Kevan PG, Clark EA, Thomas VG (1990b) Insect pollinators and sustainable agriculture. Am J Alternative Agric 5, 13-22

Knowles RP (1943) The role of insects, weather conditions and plant character in seed setting of alfalia. Sci Agric 24, 29-50

Kosior A (1987) Impact of economic activity upon bumblebee Bombus Latr population in the west Bieszczady Mts. Ochrona Przyrody 45, 239-262

Kratochwil A, Klatt M (1989) Bee species of ruderal sites in the city of Freiburg: $\mathrm{Br}$ ( $F R G$ ) Submediterranean elements in mosaic habitats with high persistence. Zool Jb Syst 116, 379-389

Kunin WE (1993) Sex and the single mustard: population density and pollinator behavior effects on seed-set. Ecology 74, 2145-2160

Lagerlöf J, Stark J, Svensson B (1992) Margins of agricultural fields as habitats for pollinating insects. Agric Ecosyst Environ 40, 117-124

Levin MD (1983) Value of bee pollination to US agriculture. Bull Entomol Soc Am 29, 50-51

Linsley EG (1946) Insect pollinators of alfalfa in California. J Econ Entomol 39, 18-29

Loring M (1981) Bees and the Law. Dadant and Sons, Hamilton, IL, USA

MacFawn D (1993) Pollination pricing. Am Bee J 133 , 845-847

MacKenzie KE, Winston $\mathrm{ML}$ (1984) Diversity and abundance of native bee pollinators on berry crops and natural vegetation in the lower Fraser Valley, British Columbia. Can Ent 116, 965-974

Maeta Y, Kitamura T (1981) Pollinating efficiency by Osmia cornifrons (Radoszkowski) in relation to required number of nesting bees for economic fruit production. Honeybee Sci 2, 65-72

Malyshev SI (1963) Wild Pollinizers in the Service of Man, Izd-vo Nauka, Moskva, Russia

Marquez J, Bosch J, Vicens N (1994) Pollens collected by wild and managed populations of the potential orchard pollinator, Osmia cornuta (Latr). J Appl Entomol 117, 353-359

McGregor SE (1976) Insect pollination of cultivated crop Plants. Agricultural Research Service, US Dept Agric

Medler JT (1956) Principles and methods for the utilization of bumblebees in cross-pollination of crops. Proc 10th Int Congr Entomol 4, 973-981

Meyer WB, Turner BL (1992) Human population growth and global land-use/cover change. Ann Rev Ecol Syst 23, 39-61
Michener CD (1979) Biogeography of the bees. Ann Missouri Bot Gdn 66, 277-347

Miliczky ER, Osgood EA (1979) The effects of spraying with Sevin-4-oil on insect pollinators in a spruce-fir forest. Maine Agric Exp Sta Tech Bull 90, 1-21

Morse RA (1960) The abundance of wild bees (Apoidea) in the northeastern United States. J Econ Entomol $53,679-680$

Munakata M (1984) Change of wild bee fauna at Narukawa between 1963 and 1973. J Hokkaido Univ Educ Sect 2B 34, 19-39

Musychenko $G$ (1937) On the insects pollinating fruit and berry plants and their ecology. Kief Acad $\mathrm{SCl}$ Inst Zool Biol 14, 226-229

Müller H (1873) Die Befruchtung der Blumen durch Insekten und die gegenseitigen Anpassungen beider, Leipzig, Germany

O'Toole C (1993) Diversity of native bees and agroecosystems. In: Hymenoptera and Biodiversity ( $P$ LaSalle, ID Gauld, eds), CAB International, Wallingford, UK

Olmstead AL, Wooten DB (1987) Bee pollination and productivity growth: the case of alfalfa. Am J Agric Econ 56-63

Orsono-Mesa $\mathrm{H}$ (1947) Observaciones antecologicas sobre recoleccion de pollen por vibracion. Caldasia $4,465-467$

Osborne J, Williams I, Corbet S (1991) Bees, pollination and habitat change in the European community. Bee World 72, 99-116

Parker FD, Batra SWT, Tepedino VJ (1987) New pollinators for our crops. Agric Zool Rev 2, 279-304

Paton DC (1993) Honeybees in the Australian environment: does Apis mellifera disrupt or benefit the native biota? Bioscience 43, 95-103

Pawlikowski T (1967) Influence of farming system on wild bees (Hymenoptera, Apoidea) in agricultural landscape. Acta Univ Nicolai Copernici Biologia 35 , 153-167

Pawlikowski T (1989a) The structure of wild bee communities from farming areas of different field sizes. Acta Univ Nicolai Copernici Biologia 33, 31-46

Pawlikowski T (1989b) The structure of wild bee communities from habitats of field-pine forest ecotone. Acta Univ Nicolai Copernici Biologia 33, 101-109

Peck O, Bolton JL (1946) Alfalfa seed production in northern Saskatchewan as affected by bees, with a report on means of increasing the populations of native bees. Sci Agric 26, 388-418

Peters G (1972) Ursachen für den Rückgang der seltenen heimischen Hummelarten (Hym, Bombus et Psithyrus). Entomol Ber 1972, 85-90

Peterson SS, Baird CR, Bitner RM (1992) Current status of the alfalfa leafcutting bee, Megachile rotundata as a pollinator of alfalfa seed. Beescience 2, 135-142 
Piper CV, Evans MW, McKee R, Morse WJ (1914) Alfalfa seed production; pollination studies. Bull US Dept Agric No 75, 1-32

Plowright RC, Pendrel BA, McLaren IA (1978) The impact of aerial fenitrothion spraying upon the population biology of bumble bees in southwestern New Brunswick. Can Entomol 110, 1145-1156

Prescott-Allen C, Prescott-Allen R (1986) The First Resource, Yale University Press, Hartford, CT, USA

Primack RB, Silander Jr JA (1975) Measuring the relative importance of different pollinators to plants. Nature (Lond) 255, 143-144

Ptacek V (1985) Testing three methods of rearing bumble bees. Sbornik Vedeckych Praci Vyzkumny A Slechtitelsky Ustav Picninarsky v Troubsko u Bma 9, 59-67

Pyke GH, Balzer L (1983) The effects of the introduced honeybee (Apis mellifera) on Australian native bees. Hawkesbury Agric Coll NSW 18-22

Rick CM (1950) Pollination relations of Lycopersicon esculentum in native and foreign regions. Evolution 4, 110-122

Robinson WS, Nowogrodzki R, Morse RA (1989) The value of honey bees as pollinators of US crops. Am Bee J129, 411-486

Röseler PF (1985) A technique for year-round rearing of Bombus terrestris (Apidae, Bombini) colonies in captivity. Apidologie 16, 165-170

Salt RW (1940) Utilize wild bees in alfalfa seed producion. Dom Dept Agric, Lethbrige Entomol Lab Leaflet No 10 FCII No 266, 1

Sax K (1922) Sterility relationships in Maine apple varieties. Maine Agric Exp Sta Bull 307, 61-76

Schemske DW, Horvitz CC (1984) Variation among floral visitors in pollination ability: a precondition for mutualism specialization. Science 225, 519-521

Schmid R (1975) Two hundred years of pollination biology: an overview. The Biologist 57, 26-35

Schreck E, Schedl W (1979) Die Bedeutung des Wildbienen - Anteils bei der Bestäubung von Apfelblüten an einem Beispiel in Nordtirol (Österreich). Ber Nat Med Ver Innsbruck 66, 95-107

Schwenninger HR (1992) Investigations on the influence of intensity of cultivation in rural areas on the occurrence of insects with special reference to the wild bees (Hymenoptera: Apoidea). Zool Jb Syst 119, 543-561

Scott-Dupree CD, Winston ML (1987) Wild bee pollinator diversity and abundance in orchard and uncultivated habitats in the Okanagan Valley, British Columbia. Can Entomol 119, 735-745

Sekita N, Yamada M (1993) Use of Osmia cornifrons for pollination of apples in Aomori prefecture, Japan. Japan Agric Res Quart 26, 264-270

Semmens TD, Turner E, Buttermore R (1993) Bombus terrestris (L) (Hymenoptera: Apidae) now established in Tasmania. J Aust Entomol Soc 32, 346
Shaw FR, Bailey JS, Bourne AJ (1939) The comparative value of honeybees in the pollination of cultivated blueberries. J Econ Entomol 32, 872-874

Sladen FWL (1918) Pollination of alfalfa by bees of the genus Megachile. Agr Gaz Canada 5, 125-126

Southwick EE, Southwick LJ (1992) Estimating the economic value of honey bees (Hymenoptera: Apidae) as agricultural pollinators in the United States. JEcon Entomol 85, 621-633

Stapel C (1943) Über die Befruchtung der Luzerne durch Insekten in Dänemark. Entomol Medd 23, 224-239

Stephen WP (1955) Alfalfa pollination in Manitoba. $J$ Econ Entomol 48, 543-548

Stubbs CS, Drummond FA, Osgood EA (1994) Osmia ribifloris biedermannii and Megachile rotundata (Hymenoptera: Megachilidae) introduced into the lowbush blueberry agroecosystem in Maine. $J$ Kans Entomol Soc 67, 173-185

Tanacs $L$ (1987) The trend of the composition of the wild-bee population on anthropogenic effects in the biotopes of the Kiskore storage-tank region at the Tisza-Valley. Tiscia (Szeged) 22, 109-119

Thomson JD, Plowright RS, Thaler GR (1985) Maticil insecticide spraying, pollinator mortality, and plant fecundity in New Brunswick forests. Can J Bot 63, 2056-2061

Thomson JD, Thomson BA (1989) Dispersal of Erythronium grandiflorum pollen by bumblebees: implications for gene flow and reproductive success. Evolution 43, 657-661

Thomson JD, Thomson BA (1992) Pollen presentation and viability schedules in animal-pollinated plants: consequences for reproductive success. In: Ecology and Evolution of Plant Reproduction: New Approaches (R Wyatt, ed), Chapman and Hall, New York, NY, USA, 1-24

Torchio PF (1990) Diversification of pollination strategies for US crops. Environ Entomol 19, 1649-1656

Torchio PF (1991) Use of Osmia lignaria propinqua (Hymenoptera: Megachilidae) as a mobile pollinator of orchard crops. Environ Entomol 20, 590-596

Torres F, Gayubo SF, Asensio E (1989) Efecto de la presion urbana sobre abejas y avispas en Salamanca. V. Superfamilia Apoidea. Commun Inst Nac Invest Agrar Ser Recur Nat 52, 1-49

Tysdal HM (1940) Is tripping necessary for seed setting in alfalfa? J Am Soc Agron 32, 570-585

van Heemert C, de Ruijter A, van den Eijnde J, van der Steen J (1990) Year-round production of bumble bee colonies for crop pollination. Bee World 71, 54-56

Vansell GH (1951) Use of honey bees in alfalfa seed production. US Dept Agric Circ 876, 1- 11

Vinson SB, Frankie GW (1990) Territorial and mating behavior of Xylocopa fimbriata $\mathrm{F}$ and $X y$ locopa gualanensis Cockerell from Costa Rica. J Insect Behav 13-32 
Vitousek PM (1994) Beyond global warming: ecology and global change. Ecology 75, 1861-1876

Vogel S, Westerkamp C (1991) Pollination: an integrating factor of biocenoses. In: Species Conservation: A Population-Biological Approach (A Seitz, V Loeschoke, eds), Birkhäuser Verlag, Basel, Switzerland

Voorhies EC, Todd FE, Galbraith JK (1933) Economic aspects of the bee industry. Univ Calif Agric Ext Bull $555,1-110$

Westerkamp C (1991) Honeybees are poor pollinators why? Pl Syst Evol 177, 71-75

Westgate VL (1911) The alfalfa caterpillar. US Dept Agric Bur Entomol Circular No 133, 1

Westrich P (1983a) Die Bienenfauna des Leudelsbachtals bei Markgröningen und ihre Veränderungen im Verlauf von 50 Jahren (Hymenoptera:Apoidea). $J b$ Ges Naturk Württemberg 138, 271-285

Westrich P (1983b) Die Bienen Baden-Württembergs 1. Megachilidae (Hymenoptera:Apoidea). Stuttgarter Beitr Naturk Ser A (Biologie) 1-50

Westrich P (1989-1990) Die Wildbienen Baden-Württembergs. Verlag Eugen Ulmer, Stuttgart, 2 vol

Wichelns D, Weaver TF, Brooks PM (1992) Estimating the impact of alkali bees on the yield and acreage of alfalfa seed. J Prod Agric 5, 512-518

Williams PH (1982) The distribution and decline of British bumble bees (Bombus Latr). J Apic Res 21, 236-245
Williams PH (1986) Environmental change and the distributions of British bumblebees (Bombus Latr). Bee World 67, 50-61

Williams PH (1989) Bumblebees and Their Decline in Britain. Centr Assoc Beekeepers, Essex, UK

Willmer PG (1991) Constraints on foraging by solitary bees. In: The Behavior and Physiology of Bees (LJ Goodman, RC Fisher, eds), CAB International, Wallingford, UK, 121-148

Wilson GF (1926) Pollination of hardy fruits: insect visitors to fruit blossoms. Ann Appl Biol 16, 602-628

Wilson GF (1933) Pollination in orchards. JR Hortic Soc $58,125-138$

Wilson P, Thomson JD (1991) Heterogeneity among floral visitors leads to discordance between removal and deposition of pollen. Ecology 72, 1503-1507

Wood GW (1961) The influence of honeybee pollination on fruit set of the lowbush blueberry. Can J Plant Sci 41, 332-335

Wood GW (1979) Recuperation of native bee populations in blueberry fields exposed to drift of Fenitrothion from forest spray operations in New Brunswick. J Econ Entomol 72, 36-39

Young HJ, Stanton ML (1990) Influences of floral variation on pollen removal and seed production in wild radish. Ecology 71, 536-547

Zöckler C (1988) Feuchtwiesenflora und blütenbesuchende Insekten. Ihre Bedeutung für die Grünlandextensivierung-Faun. Ökol Mitt 6, 5-19 